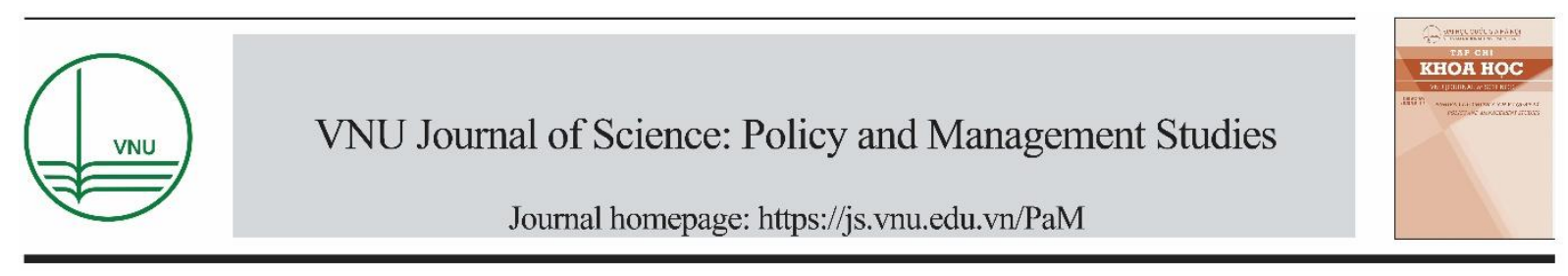

\title{
Inclusive Learning Environment for Students with Disabilities in Vietnam's Higher Education: An Analysis of the Existing Policies and Legal Framework
}

\author{
Nguyen Thuy Anh* \\ VNU University of Economics and Business, 144 Xuan Thuy, Cau Giay, Hanoi, Vietnam \\ Received 28 November 2018 \\ Revised 18 December 2018; Accepted 22 December 2018
}

\begin{abstract}
Vietnam is one of the countries that have the highest number of persons with disabilities (PWDs). According to the 2009 Census, there were approximately 6.1 million PWDs, accounting for $7.8 \%$ of the Vietnamese population. Research has shown that the number of PWDs who attend higher education in Vietnam is extremely low and only $0.1 \%$ of PWDs have completed a bachelor program. The purpose of this paper is to provide an overview of the status of PWDs in Vietnam as well as to analyze the country's legal framework and policies governing PWDs. To this end, the paper firstly presents facts and figures regarding PWDs in Vietnam. Secondly, the paper reviews Vietnam's commitments to international policies and standards, and the legal framework and policies on PWDs in general and students with disabilities (SWDs) in particular at the national level. Finally, the study points out some issues and challenges for Vietnam in creating a more inclusive learning environment for PWDs and SWDs at higher education.
\end{abstract}

Keywords: People with disabilities, students with disabilities, higher education in Vietnam, inclusive learning environment.

\section{Introduction}

According to the World Health Organization in the past decades the ratio of PWDs has been rising worldwide from $10 \%$ of the world's population in the 1970s to about $15 \%$ in 2011 . These are people who live "with some form of disability, of whom $2-4 \%$

\footnotetext{
* Tel.: 84-367441701.

Email: maichithuyanh@gmail.com

https://doi.org/10.25073/2588-1116/vnupam.4162
}

experience significant difficulties in functioning" [1]. With the effort to create a more developed and equal world the global community has made considerable movements towards the issue of inclusion for PWDs. In 1989, the UN Convention on the Rights of the Child (CRC) was affirmed that the rights of each child need to be respected and ensured without any kind of discrimination including disability [2]. There has been a transition in the understanding of disability that has shifted from "the medical model" and "the charity model" to 
"the social model" in which people are viewed as being disabled by the social, cultural and economic barriers rather than by their own bodies [3, 4]. This social model includes human rights and this was reflected in the $2006 \mathrm{UN}$ Convention on the Rights of Persons with Disabilities (CRPD) [4]. Among the rights that PWDs are equal to have such as the rights to health care and social participation, is the rights to education. The benefits of education for CDWs are significant and have been affirmed in previous research that education can empower CWDs by increasing their awareness of their choices and reducing their dependency and vulnerability [5]. However as noted in The Millennium Development Goals Report 2010 children with disabilities have to face with limited opportunities and there is a link between disability and marginalization in education $[6$, 7]. It is also pointed out that CWDs are less likely to start school, have lower rates of school attendance, and lower transition rates to higher levels of education. This fact has called for actions from countries all over the world including Vietnam [7].

Located in Southeast Asia, Vietnam has a population of over 94 million people ${ }^{1}$, which is equivalent to $1.26 \%$ of the world's total population. Its population growth rate is around $1 \%$ per year. In 1986, Vietnam started its political and economic reform called "Doi Moi" which shifted the centrally planned economy to a market economy. This resulted in a remarkable transformation of Vietnam from one of the poorest countries in the world into a lower middle-income country. Since Doi Moi, Vietnam has experienced a strong and rapid economic development with annual GDP per capita growth ranked among the fastest in the world, averaging $6.4 \%$ a year in the $2000 \mathrm{~s}^{2}$. As

\footnotetext{
${ }^{1}$ World Bank. Available at

https://data.worldbank.org/country/vietnam?view=chart (Accessed on August 22, 2018)

${ }^{2}$ World Bank. Available at http://www.worldbank.org/en/country/vietnam/overview (access on May 2nd, 2018).
}

of 2017, Vietnam's GDP was estimated to reach USD 223.864 billion. Vietnam's admission to the World Trade Organization (WTO) on January 11, 2017 has opened a wide door for its integration to enter the global playground with regional and international countries. The economic structure has been encouraging to increase the proportion of industry and services and reduce the ratio of agriculture. By means of economic achievements, in recent years, Vietnam has been attaching special importance to investments on education, health care, social welfare, and social services, contributing to the upgrade of human development index (HDI). Vietnam's HDI value for 2015 was 0.683 , which was $43.2 \%$ higher than the value of 0.477 in 1990 , positioning it at 114 out of 187 countries and territories in the world ${ }^{3}$. The health status of Vietnamese people has also improved over the years, such as life expectancy at birth increasing to 76 years in $2015^{4}$, and infant mortality rates reducing by $3.3 \%$ from 1990 to $2016^{5}$. Since joining the Association of Southeast Asian Nations (ASEAN) as a full member on 28 July 2015, Vietnam's position has become more critical as it is catching up to the economies of "Tier 1" ASEAN members. Vietnam is also one of the most active members in the region in terms of foreign policy. In the past years Vietnam has made strong commitments to support PWDs. Before signing and ratifying the CRCD in 2007 and 2014, Vietnam enacted the Ordinance on Disabled Persons in 1998, which then was replaced by the 2010 Law on PWDs. The Government also issued the National Action Plan to support PWDs for the period 2006-2010 and a dozen of decrees that took remarkable protection to PWDs.

3 UNDP. Human Development Report 2016. Human Development for Everyone - Briefing note for countries on the 2016 Human Development Report - Vietnam.

4 UNDP. Human Development Report 2016. Human Development for Everyone - Briefing note for countries on the 2016 Human Development Report - Vietnam.

5 The United Nations Inter-agency Group for Estimation Child Mortality. Levels \& trends in child mortality. 2017. 
This study aims to provide an overview of the status of PWDs in Vietnam by reviewing the Vietnamese regulations and policies on PWDs in comparison with international documents and trends to evaluate the commitment of the Vietnamese Government on guaranteeing and implementing PWDs' rights. The paper also presents facts and figures concerning PWDs and SWDs at the higher education level in Vietnam, based on which it gives some analyses on the issues and challenges that Vietnam is having in this field.

\section{Persons with disabilities in Vietnam}

\subsection{Definition of PWDs in Vietnam}

According to the Vietnam's National Law on Persons with Disabilities, No. $51 / 2010 / \mathrm{QH} 12$, which was passed by the National Assembly on 17 June 2010 and became effective on 1 January 2011, persons with disabilities "are those who have impairment of one or more parts of their body, which are shown in different forms of disability, and may cause difficulties in work, daily life and learning" [8].

More specifically, Vietnam adopts the definitions of impairment, disability, and handicap introduced by the World Health Organization [9], as follows:

Impairment (organ level): loss or abnormality of body structure or of a physiological or psychological function. Impairment may be the result of disease or accident, or of congenital or environmental agents.

Disability (individual level): reduced or absence of ability to perform as a result of impairment; the restriction or absence of a function (moving, hearing, or communicating).

Handicap (social level): disadvantages experienced by a person as a result of a disability. The result of an interaction between an individual with impairment or disability and barriers in social, cultural, or physical environment so that this person cannot take part in mainstream community life on an equal level or fulfil a role that is normal [9].

As classified by the Law, there are six main types of disability as follow:

1. Mobility disability;

2. Hearing and speaking disability;

3. Visual/seeing disability;

4. Mental disability;

5. Intellectual disability;

6. Other disabilities/impairments [8]

The Law classifies the severity of disability into three levels including:

1. Persons with severe disability are those who are unable to support themselves in their daily activities.

2. Persons with moderate disability are those who are able to support themselves in some of their daily activities.

3. Persons with minor disabilities are those who do not fall under either type 1 or 2. [8]

The Ministry of Labour, Invalids and Social Affairs (MOLISA) and the National Coordinating Council on Disability (NCCD) established according to Decision No. 1717/QĐ-TTg on October $6^{\text {th }}, 2015$, are the two government focal agencies on disability matters.

\subsection{The number of Persons With Disabilities in Vietnam}

According to the 2009 Vietnam's Population and Housing Census, there is $7.8 \%$ of the 78.5 million persons aged 5 years or older, or 6.1 million people in Vietnam live with one or more disabilities in seeing, hearing, walking or cognition. The 2009 Census also shows that $75 \%$ of the persons with disabilities live in rural areas and $32.5 \%$ are classified as poor households. $53.8 \%$ of the PWDs are female and $46.2 \%$ are male. Regarding the distribution of disability by age group, $41.8 \%$ are of working age (from 16 to 59 years old), while children from 5 to 15 years old account 
for $3.8 \%$ and $54.6 \%$ are PWDs aged 60 or older [10]. Physical disability is the most popular among the six types, accounting for $29.4 \%$, while visual, hearing, mental, intellectual and multiple disability make up $13.8 \%, 9.3 \%$, $16.8 \%, 13.6 \%$ and $17.0 \%$ respectively [10].

The literacy rate of adult PWDs aged 16 years or older is $76.3 \%$, which is much lower than that of persons without disabilities in the same age group $(95.2 \%)$. This difference even increases along with the level of disabilities.
The literacy rate is only $45.4 \%$ for adult people with severe disabilities (PWSDs) [11] (See: Figure 1). According to the data of Vietnam Assistance for the Handicapped "the higher the schooling level, the lower the number of PWDs" [12]. It showed that PWDs having elementary education marked up $57.6 \%$ while the percentage of those attending higher education or no schooling is $9.7 \%$ and $8.9 \%$, respectively [12].

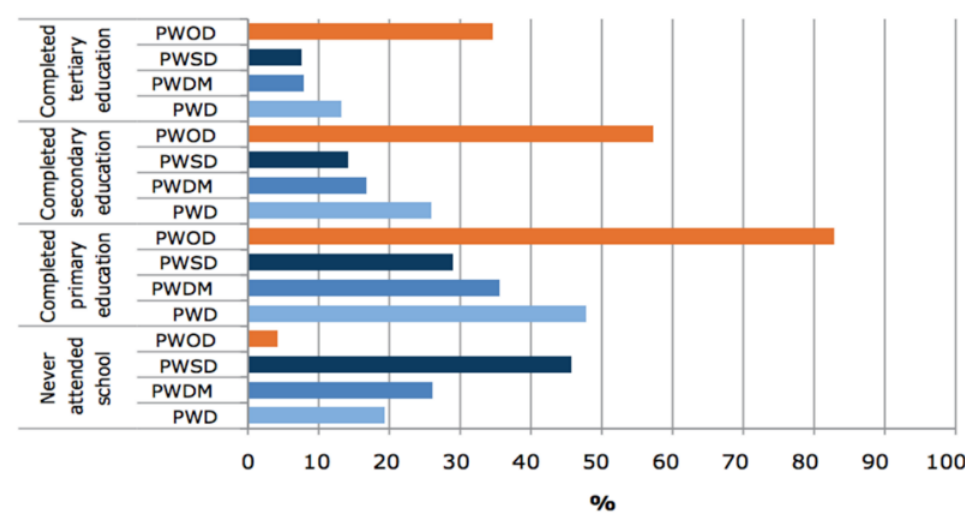

Figure 1. School attendance and completion rates of adults aged 16 years or older in Vietnam by disability status. Source: UNFPA, 2011

Lack of education means lack of job opportunities. The proportion of PWDs participating in the labour force at $72 \%$ is lower than that of PWODs at $82 \%$. This rate is significantly low for PWSDs (25\%). Unemployment rate of PWDs is therefore higher in comparison with the non-disabled population [11] (See the Figure 2).

\subsection{Rights, Benefits and Privileges of PWDs}

As stipulated in Article 4 of the Law on PWDs 2010, in addition to the rights that a PWD enjoys as other individuals without disability/ies, a person with disability/ies shall have rights to:

a) Equal participation as other members in all social activities; b) Independent living and inclusion into the community and society;

c) Be exempted or reduced financial contribution to the social activities;

d) Be entitled to the policies and support of the State including health care, rehabilitation, education, employment, vocational training, cultural services, sports and entertainment, public places, means of transport, information technology that are suitable/appropriate to the person's psychology, physical, health and personal characters.

e) Other rights as regulated by laws. [8]

Pursuant to the Law, in terms of scientific research and production of orthopedics and rehabilitation equipment "the State shall provide financial support through projects to 


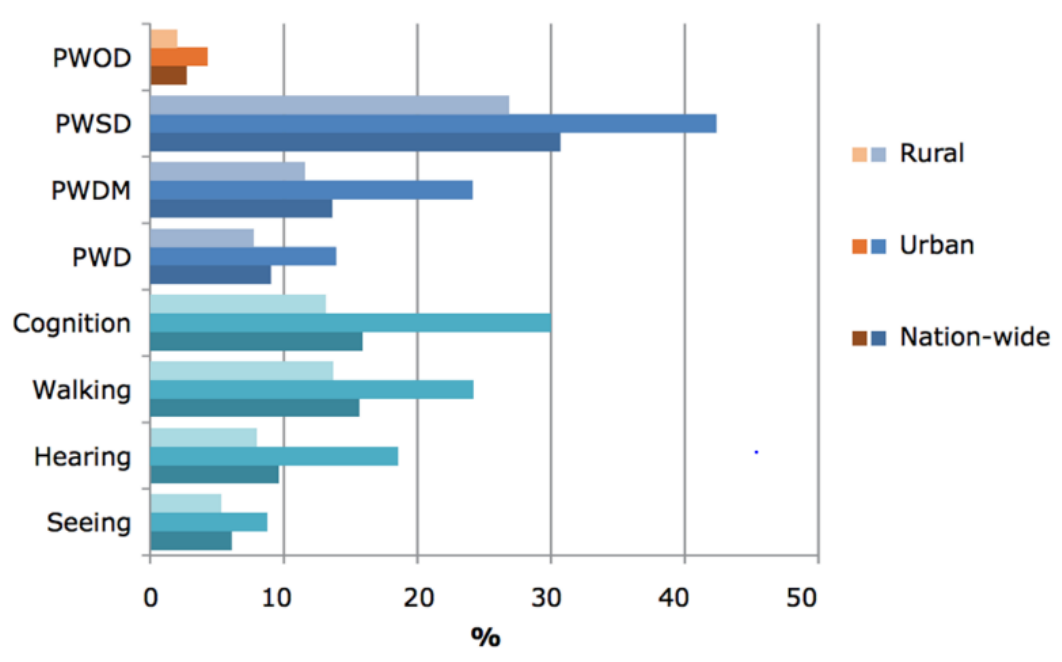

Figure 2. Unemployment rate by disability status in Vietnam.

Source: UNFPA, 2011

institutions, organizations that conduct scientific research and training experts on orthopedics and rehabilitation. Enterprises who produce orthopedics equipment and assistive devices that support persons with disabilities to lead daily life, study, and work are entitled to borrow loan with preferential interest rate and tax exempt or reduction. Orthopedic Equipment that are provided through non- refundable aid programs and projects donated by foreign individuals and organizations shall be exempt from tax or pay reduced tax in accordance with current legislation" [8]. Similarly, regarding information technology and communications, Article 43 stipulates that the "State shall have preferential treatment policies in tax, credit and other incentives for research and production of assistive devices to support persons with disabilities to access and use information technology and communications services" [8].

PWDs can enjoy other such privileges as those related to means of public transport. According to Article 42, "public means of transport must have seats reserved for persons with disabilities, be equipped with assistive devices to support persons with disabilities to get in and out, and other equipment necessary to assist persons with disabilities" and "means of transport with accessibility features as regulated by the National Code and Standards shall be tax exempted according to the law" [8].

\subsection{Employment opportunities}

Article 33 of the Law on PWDs stipulates on employment for PWDs as follows:

1. The State shall ensure rights of persons with disabilities to vocational rehabilitation, free of charge job counselling, job retention and job placement in accordance with the health and types of disabilities.

2. Institutions, agencies, organizations, enterprises and individuals shall not reject job applications of persons with disabilities who are qualified for the positions and shall not create recruitment criteria which are not in accordance with the law with an aim to limit job opportunities for persons with disabilities;

3. Institutions, agencies, organizations, enterprises and individuals employing persons with disabilities must place them in the jobs that are suitable to health conditions and qualification of persons with disabilities and execute all regulations on employees with disabilities; 
4. Institutions, agencies, organizations, enterprises and individuals employing persons with disabilities shall comply with the provisions of employment legislation for persons with disabilities.

5. Employment/job services are responsible for providing orientation and counselling to help persons with disabilities to find jobs;

6. Persons with disabilities who self employ shall be entitled to borrow loan with low interest rate for business development; to be trained in business management, technology transfer, and marketing of products in accordance with the current State legislation. [8].

According to Article 34 and Article 35 of the Law, business enterprises who employ more than $30 \%$ of their labour force as PWDs shall be supported with adjusting working environment, tax exemption, borrowing loan with low interest rates. They will also be allocated land or can rent land with exemption or reduction of land lease payment. Organizations, institutions, and enterprises are encouraged to employ PWDs and shall be entitled to enjoy preferential policies [8].

\section{Commitment to international and regional policies and standards}

It can be seen that the Vietnamese Government has made an impressive progression to protect the rights of PWDs complying with the international standards and commitments. In 1990 Vietnam ratified the UN Convention on the Rights of the Child (CRC). In 2007 Vietnam signed the UN Convention on the Rights of Persons with Disabilities (CRPD), which was then ratified in 2014. In 2016, the Prime Minister signed Decision No. 1100/QĐ$\mathrm{TTg}$ on June $21^{\text {st }}$ ratifying the plan for implementing the CRPD with the purpose to significantly identify the responsibilities of different governmental bodies and institutions at various levels and fields in order to effectively implement the rights and responsibilities of a member country of the Convention [13].
In May 2015, together with participants from 160 countries, a delegation of Vietnam participated in the World Education Forum and adopted the Incheon Declaration and Framework for Action, which sets out a new vision for education for the next fifteen years, in order to ensure inclusive and equitable quality education and promote lifelong learning opportunities for all ${ }^{6}$.

In April 2000, in Dakar, Senegal, Vietnam made the UNESCO Education For All (EFA) commitments at the International World Education Forum. In order to implement these commitments Viet Nam then developed the National EFA Action Plan for the period of 2003 to 2015 approved by the Prime Minister in Decision No. 872/CP-KG dated 2 July 2003 [14].

The National EFA Action Plan aims to achieve the global EFA goals:

Goal 1: Expand and improve comprehensive ECCE, especially for disadvantaged and highly vulnerable children.

Goal 2: Ensure that by 2015 all children, particularly girls, children in difficult circumstances and those belonging to ethnic minorities have access to, and complete, free and compulsory primary education of good quality.

Goal 3: Ensure that the learning needs of all young people and adults are met through equitable access to appropriate learning and life- skills programs.

Goal 4: Achieve a 50 per cent improvement in levels of adult literacy by 2015, especially for women, and equitable access to basic and continuing education for all adults.

Goal 5: Eliminate gender disparities in primary and secondary education by 2005 , and achieve gender equality in education by 2015 , with a focus on ensuring girls' full and equal access to and achievement in basic education of good quality. Goal 6: Improve all aspects of the quality of education and ensure excellence of all so that recognizable and measurable learning outcomes are achieved by all, especially in literacy, numeracy and essential life skills. [14] 


\section{Existing policies and legal framework governing PWDs in Vietnam}

The period of 2011 to $20^{6}$

15 is considered to be the time of institutionalization of laws and policies towards PWDs in Vietnam which have been relatively completed, thorough and united including one National Law on PWDs, a number Laws with integrating contents, 5 Decrees, 16 Circulars, 10 Decisions issued by Prime Minister?

The 1992 Constitution of Vietnam and its amendments in 2001 and 2013 affirm the undeniable equal rights of all citizens, including PWDs. The protection of and support for PWDs are stipulated in Articles 59 and 61. According to Article 59, "[T] he old, the disabled people, orphans are supported by the State. The State and the society create favorable conditions for the disabled children to study and to take a suitable vocation" [15]. Article 61 confirms that the State shall "provide favorable conditions for the disabled and the poor to access to cultural and vocational learning" [15]. The Constitution has formed the fundamental base for the construction of more specific and direct policies to support PWDs in many aspects of life. [9].

On July 30th 1998, the Standing Committee of the National Assembly promulgated the Ordinance for Disabled Persons that stipulates clearly roles and responsibilities of government bodies, society and families towards PWDs and affirms their rights in key areas of life, including health, education, employment and social participation. The Ordinance also defines the date of April 18th to be the Day of Care and Protection of Persons with Disabilities [9].

Together with the Ordinance on Disabled Persons in 1998, the Law on Disability in 2010 is one of the two most comprehensive legal

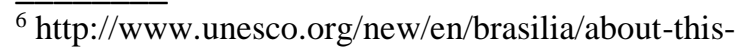
office/singleview/news/education_2030_incheon_declaration_an d_framework_for_action/

7 http//btxh_ov_vn/danh-muc-tin/ncd/le-ra-mat-uy-ban-quodha ta jobs to 300,000 working-age persons with disabilities, $70 \%$ disabled children with learning ability can have access to education, $100 \%$ PWDs have legal services when needed.
}

documents on disabilities in Vietnam. The enactment of the 2010 Law on Disability which incorporated the rights-based approach and the non-discrimination principles of the CRPD aims at ensuring equal opportunities for PWDs to have access to all aspects of the society such as policies in social protection, employment, education, health care, construction, transportation.

In 2014 the National Technical Regulation on Construction for Disabled Access to Buildings and Facilities was promulgated by the Ministry of Construction together with Circular No. 21/2014/TT-BXD dated $29^{\text {th }}$ December, in replacement of the Building Code of Construction Accessibility for People with Disabilities issued in 2002 with Decision No. 01/2002/QĐ-BXD. This barrier-free code and standards lays out compulsory technical requirements when newly construct or improve existing construction works ensuring the accessibility for PWDs. These constructions include apartment buildings, public infrastructures such as public sector office buildings, medical examination and treatment facilities, educational and vocational training facilities; cultural and sports constructions, hotels, commerce and services buildings, train stations, ports, bus stops, and other convenient urban infrastructures [16].

The National Action Plan to Support People with Disabilities for 2012-2020 approved by the Prime Minister in August, 2012 aims at supporting PWDs so that they can make the most of the capacities in order to meet self demands, creating favorable conditions for PWDs to equally strive to participate in socioeconomic activities contributing to the society and community's development [17]. The National Action Plan sets up a number of targets to be achieved by 2020 including the provision of vocational training and suitable 
accessibility to public buildings and transportation, early intervention, inclusive education, medical services, and information technology and communication [17].

In addition to the aforementioned legal framework and policies, Vietnam has passed a lot of Laws which provide additional rights to PWDs, including 1989 Law on Protection of People's Health, the 1999 Penal Law, the 2000 Law on Marriage and Family, the 1991 Law on Universalization of Primary Education, the 2004 Law on Protection, Care and Education of Children, the 2005 Education Law, the 2006 Law on Vocational Training, the 2006 Law on Information Technology, the 2006 Law on Sports and Physical Education, and the 2008 Law on In-land Transportation, 2012 Labor Code, etc. Besides there are at least 20 different directives, decrees and decisions relating to disability in such areas as labor and employment, vocational training, accessible transportation, building construction standards for residential and commercial buildings, welfare policies, teacher training, and sports [18].

\section{Background of inclusive education in Vietnam}

Pursuant to the Law on PWDs there are three approaches of education for PWDs including inclusive education, special education and semi-inclusive (integrated) education. Article 2 defines these three approaches as follows:

1. Inclusive education is an educational approach that accommodates both persons with disabilities and persons without disabilities in educational establishments.

2. Special education is an educational approach that is exclusively for persons with disabilities in educational establishments.

3. Semi-inclusive education is an educational approach that combines inclusive and special education for persons with disabilities in educational establishments [8]
It is stipulated by the Law in Article 28 that PWDs are encouraged to participate in the inclusive education, which is considered to be the main approach of education for PWDs. Semi-inclusive and special education are applied only in the case there are not enough conditions for PWDs to pursue inclusive education [8].

In 2006 the Ministry of Education and Training (MOET) issued Decision No.23/2006/QĐ-BGDĐT on Inclusive Education for Disabled and Handicapped Persons. Recently on January $29^{\text {th }}$, 2018, MOET promulgated Circular No.03/2018/TTBGDĐT on Inclusive Education for Persons with Disabilities. Accordingly, the purpose of inclusive education is that PWDs are able to develop their own capacity, integrate and have more opportunities to contribute to the community; ensure the rights to equal, quality and appropriate education with the characteristics and ability of PWDs [19].

There are several differences between the two documents in terms of the rights of PWDs, although the number of items is the same, the details of some contents have been revised in the updated one. More specifically both documents stipulate that PWDs can enroll at higher ages compared to the ordinary regulated enrollment ages. However, while Article 19 of the 2006 Decision details that PWDs can be exempted from some courses if their physical disabilities do not allow them to take, or they can enjoy prioritized policy for admission when applying in higher education institutions and other favorable conditions during the course of their study. The 2008 Circular has briefed these contents in item 7, mentioning Joint Circular No.42/2013/TTLT-BGDĐT-BLĐTBXH-BTC promulgated by the MOET together with the Ministry of Labor, Invalid and Social Affairs (MOLISA) and the Ministry of Finance (MOF), which concretely regulates the educational policy for PDWs. This Joint Circular will be discussed later in the paper. One new content is added in Article 15 of Circular 03/2018 compared to Decision 23/2006 is the rights of 
PWDs to information security of their disabled situation.

It is recorded that Viet Nam has about 1.2 million children with disabilities (CWDs), of which $27 \%$ have intellectual disabilities, $20 \%$ have mobility disabilities, $19 \%$ have speaking disabilities, $12.43 \%$ have hearing impairment, $12 \%$ have visual impairment and $7 \%$ have other types of disabilities. Children with severe and especially severe disabilities account for about $31 \%$ of the total CWDs, while multihandicapped children make up $12.62 \%$. Causes of the disabilities include innate causes (72.38\%), illness $(24.34 \%)$, accidents (3.93\%), and birth difficulties (2.28\%) [14].

In the academic year of 2017-2018 Vietnam has $8,041,842$ students in primary education ${ }^{8}$. Another report from the Ministry of Education and Training shows that there are 52,711 of the CWDs participated in inclusive education, and 16,000 participated in special education [14]. So far the MOET has implemented policies to support both students with disabilities and teachers have access to and participate in education for PWDs. These policies include promoting the training and retraining of management and skilled teachers for education of CWDs, improve learning facilities, and equipping schools with specialized teaching aids to enhance the quality of education for CWDs [14]. As a result, it is reported that learning outcomes of SWDs have been significantly improved. The percentage of students classified as having above average learning capacity has increased to $48.5 \%$, and the number of SWDs repeating grades or dropping out has remarkably decreased [14]. However, there is a fact that although CWDs are encouraged to have inclusive education with non-disabled students at regular schools, few regular schools can appropriately accommodate CWDs [20]. On the other hand, parents of children without disabilities are reluctant to send their kids to special schools to study

\footnotetext{
${ }^{8}$ http://moet.gov.vn/thong-ke/Pages/thong-ke-giao-ductieu-hoc.aspx?ItemID=5392
}

inclusively with CWDs, particularly with those children who have learning disabilities [20].

\section{Higher education institutions in Vietnam}

According to statistical data from the Ministry of Education and Training, in academic year of 2016-2017, there are 235 higher education institutions (HEIs) in Vietnam. This number does not include those in the field of Security and Military. Among these 235 HEIs, 170 are public and 65 are private institutions. The total number of enrolment in this academic year is 418,991 students of which 354,193 students enrolled in public and the rest enrol in private HEIs. Up to 2017 the number of students at higher education level in Vietnam is $1,767,879$, most of which study at public HEIs (1,523,904 students) [21].

Regarding the number of students with disabilities at HEIs in Vietnam, so far MOET has not collected such data from colleges and universities. The Ministry is planning to collect and add these data into the national annual statistics from 2018 according to Decision No.338/QĐ-BGDĐT on Education for Persons with Disabilities Plan Period 2018-2020. Based on the information of $\mathrm{WHO}$, there is only $0.1 \%$ of the total PWDs in Vietnam obtain Bachelor degree and $6.5 \%$ have Certificate of Professional Practising 9 .

Annually education accounts for $20 \%$ of the total government expenditure, equivalent to about 5\% of GDP. This proportion is considered to be relatively high compared to other countries in the region and the world over. Spending on vocational training, colleges, universities and continuing education makes up $30 \%$ of the total expenditure on education, $12 \%$ of this budget is allocated to colleges and universities [22].

\footnotetext{
$\overline{9}$ https://thanhnien.vn/giao-duc/ly-do-khien-sinhvien-khuyet-tat-bo-hoc-690495.html)
} 


\section{Existing policy and legal framework on persons with disabilities in higher education institutions in Vietnam}

As previously mentioned, in recent years Vietnam has step by step complete the legal and policy framework on PWDs in general and PWDs at higher education in particular.

As stipulated by the 2010 Law on PWDs, it is unlawful for educational establishments if they refuse to accept PWDs to study in their institutions. PWDs are given priority in student recruitment. They are also entitled to exemption from or reduction of school fees and other training-related payments. PWDs can be considered to receive scholarships and supports in study means and materials [8]. These contents are later concretely regulated in other under law legislations related to higher education.

First, educational institutions in general and HEIs in particular have the responsibility to accept and accommodate PWDs. Colleges and universities need to arrange suitable classes so that each inclusive class contains no more than 02 PWDs. In special cases, based on reality, more PWDs can be allocated in one class as long as it can meet the learning demands of PWDs [19].

Second, with regards to the admission of PWDs in HEIs, MOET promulgated Circular No. 05/2017/TT-BGDĐT: Regulation on Fulltime University Admission; Full-time College Admission in Teacher Training Fields dated January $25^{\text {th }}, 2017$. More specifically, while Item 1 of Article 7 stipulates that persons with severe disabilities having certificates issued by authorized offices can enjoy prioritized admission policy, Item 2 of Article 7 states that for applicants with extremely severe disabilities having certificates, rectors of the HEIs can decide to directly accept these students based on the consideration of their learning outcomes at high schools, their health situation and the requirements of the educational fields [23].

Third, in 2013 Joint Circular No.42/2013/TTLT-BGDĐT-BLĐTBXH-BTC issued by the three ministries mentioned in the previous part specifies the policies on scholarships and supports for PWDs in terms of means and learning materials. According to Article 7 PWDs from poor and near-poor households studying at educational establishments can receive a monthly scholarship equal to $80 \%$ of the basic salary level as regulated by the Government in each period of time, and a financial support with one million VNDs per person a year to purchase means and learning materials [24]. Later in 2015, the Government promulgated Decree No. 86/2015/ND-CP dated October $2^{\text {nd }}, 2015$, on Mechanism for Collection and Management of Tuition Fees Applicable to Educational Institutions in the National Education System and Policies on Tuition Fee Exemption and Reduction and Financial Support from Academic Year 2015-2016 to 2020-2021. Article 7 of this Decree stipulates that students with disabilities who have financial difficulties are exempted from tuition fee payment.

\section{Issues and challenges}

\subsection{The issue of Disability Definition}

The current definition of disability according to the 2010 Law on Persons with Disabilities defines that: "Person with disabilities means a person who is impaired in one or more body parts or suffers functional decline manifested in the form of disability which causes difficulties to his/her work, daily life and study" [8]. It can be said that the Law's definition of PWDs is not congruent with the current definition of the ICF/CRPD in the way that it ignores the impairments from society, from the system that makes the person become disabled. The Vietnamese definition belongs to the Medical model which considers disability as a personal problem and sees PWDs as helpless people who need special treatment, education and occupations in order to function in daily life [25]. 


\subsection{Conflict regulations between Law and Decree on PWDs regarding tuition fee exemption for $S W D s$}

Pursuant to the Article 27 of 2010 Law on PWDs: "PWDs are entitled to exemption or reduction of school fees, training expenses and other contributions". However, the Decree No 86/2015/ND-CP on mechanism for collection and management of tuition fees applicable to educational institutions regulated that only disabled students who encounter financial difficulties are eligible for tuition fee exemption. Despite the perspective that some people could consider this new regulation as the equality for PWDs, this regulation may cause troubles for universities during implementation when there is not a consensus between Law and documents under law. In reality, it requires SWDs to submit documents issued by the provincial People's committee to certify that their families belong to poor or near poor households. This regulation took effects on December 01, 2015 and is applicable to the academic years from 2015-2016 to 2020-2021. This leads to the fact that some SWDs are not eligible to be exempted from tuition fees since the academic year 2016-2017 and creates one more challenges and obstacles for SWDs in entering and fulfilling the higher education.

\subsection{Methods of determining levels of disabilities}

Under the regulations of the 2010 Law on PWDs the Disability Degree Determination Council established by the Chairman of Commune or Ward's People's Committee shall determine the degree of disability of PWDs. The Ministry of Health (MOH) and MOLISA are the primary ministries in charge of implementing policies related to the identification of disability and the issuance of the Disability certificates. In order to obtain a certificate of disability, a PWD or his/her family needs to apply for an assessment of disability to either the Medical Appraisal Council through the $\mathrm{MOH}$ or the Disability
Degree Determination Council. A number of decrees and circulars related to this identification process have been issued such as: Decree 28, Circular 34, Joint Circular 37. However, it is said that such documents have just regulated a limited forms of disability [26]. In addition, the procedure to certify the forms and levels of disability in Vietnam now is mainly carried out by direct observations of PWDs through their simple activities of serving their personal daily life. The procedure is really simple, depends much on the feeling of the observers. Because of no standard process and unclear signals of changing nature of disability, some hidden disabilities like learning disabilities could not be identified hindering PWDs to obtain the certificate of disability [7].

This issue causes two serious cases: First, PWDs are not recognized and are not granted disability certificate. This makes PWDs difficult to approach reasonable learning methods or suitable educational environment as well as to receive any support. Second, persons with slight impairments may be certified as PWDs which caused the inaccurate assessment.

\subsection{Lack of accurate and reliable data on SWDs}

Until now, the exact number of PWDs in Vietnam has been the biggest and most controversial issue. There is no official national disability rate in Vietnam [25, 12]. In addition, there is always a huge gap between different reports on PWDs in Vietnam. For example, figure of $7.8 \%$ of people aged 5 years or older are disabled person in comparison to that of the 2006 Viet Nam Household Living Standards Survey which announced the number of $15.3 \%$, whereas a report from the World Health Organization (WHO) showed that disabled persons accounted for $15.5 \%$ of the country's population. The possible reason for statistical discrepancies is probably due to a possible difference of criteria used by MOLISA and the Ministry of Health. Le Minh Hang [25] agreed that the reason for this may be because of the differences in the definitions of disabilities and 
the wording of the survey questions. Similar to other scholars, Tran Van Kham [12] said "many surveys were conducted in small scales and for specific purposes which could not provide an overall status of PWDs in Vietnam as well as the reliable and exact rate of PWD in Vietnam".

Notably there are no available data of SWDs in universities in Vietnam. When being contacted by the author for the number of SWDs in Vietnam, the National Coordinating Council on Disability (NCCD) said that the data of SWDs in university has never been collected before. This answer reflects the fact that although there are various legal documents issued to guarantee the equality and rights of PWDs, the gap between theory and reality is still high. In addition, it also shows that authorities did not fulfil their responsibility of adopting a data management system provided in the Circular 39/2009/TT-BGD-DT [26].

The accurate and reliable data of PWDs is the important key to monitor the implementation of CRPD of the Vietnamese Government as well as to enhance the awareness of society on PWDs' rights. Relating to the data on SWDs, having a tool that can check the status of enrolment, leaving or graduation from higher education institutions annually may help the Government reduce the rate of unemployment of PWDs as well as develop necessary informed policy to the SWDs who keep trying to study higher.

\subsection{Hard learning environment for SWDs}

Vietnamese universities have not paid attention to and invested on campus facilities and infrastructures so as to make inclusive learning environment for SWDs. Disabled students face with a lot of difficulties and obstacles in terms of the accessibility and learning resources. This causes negative impacts on their learning and research at the university. This fact requires both national and ministerial bodies as well as institutional managers to allocate sufficient financial resources and have sufficient policies to invest in these important components of university campuses. More specifically, pathways for wheelchairs, elevators, standard toilets for PWDs, Braille learning materials and Braille signs at public places, among others need to be invested in in the coming near time to come.

\subsection{Soft learning environment for SWDs}

Lecturers and staff members are important stakeholders that interact with SWDs on a daily basis. However most of them have not been trained to communicate with or interact or help SWDs who must have special needs [25]. There should be more activities and movements within university campuses so as to raise the awareness of managers, lecturers, staff members, students and parents towards the need for creating a more inclusive environment for SWDs and that it is the responsibility of every one. The role of student clubs and youth union is very important in not only helping SWDs in study but also in joining the community and having confidence, joyfulness as well as making the most of their ability.

Financial issues are also among the obstacles that SWDs have due to the fact that many SWDs come from the rural areas or from families with financial difficulties. SWDs should be exempted from tuition fee payment without the condition of having a certificate of poor household.

\section{Conclusion}

In order to have a better understanding of the situation of the learning environment at higher education institutions in Vietnam further study needs to be conducted with a wide pool of stakeholders including not only SWDs, but also SWODs, managers, lecturers, staff members, parents and policy makers. The study can be widened to PWDs who have not enrolled in a university. More data at both national and institutional levels need to be collected by responsible bodies so as to have informed 
policies and better implementation of legislative documents.

\section{Acknowledgements}

I would like to express my sincere gratitude to the University of Malaya, the AUN-DPP and the Nippon Foundation for the financial and logistical support to conduct this research.

\section{References}

[1] World Health Organization [and] The World Bank. (2011). World report on disability. Geneva, Switzerland :World Health Organization.

[2] United Nations. (1989). Convention on the Rights of the Child. Treaty Series, 1577, 3.

[3] Oliver, M. (1990). The Politics of Disablement. London: Macmillan.

[4] United Nations. (2011). Disability and the Millennium Development Goals: A Review of the MDG Process and Strategies for Inclusion of Disability Issues in Millennium Development Goal Efforts. New York: The United Nations.

[5] Mont, D. and Nguyen, V.C. (2011). Disability and Poverty in Vietnam, The World Bank Economic Review, Vol. 25, No. 2, pp. 323-359.

[6] United Nations. (2010). The Millennium Development Goals Report 2010. New York: The United Nations.

[7] UNICEF. (2015). Readiness for education of Children with Disabilities in eight provinces of Vietnam. Hanoi: UNICEF Vietnam.

[8] National Assembly. (2010). The National Law on Persons with Disabilities. Hanoi: National Assembly.

[9] Le Bach Duong, Khuat Thu Hong, Nguyen Duc Vinh. (2006). People with Disabilities in Vietnam: Findings from a social survey at Dong Nai, Quang Nam, Da Nang, and Thai Binh. Hanoi: Institute for Social Development Studies.

[10] UNESCAP. (2015). Disability at a Glance 2015: Strengthening Employment Prospects for Persons with Disabilities in Asia and the Pacific. Bangkok: United Nations Economic and Social Commission for Asia and the Pacific.

[11] UNFPA. (2011). People with Disabilities in Viet Nam, Key Findings from the 2009 Viet Nam Population and Housing Census. $\mathrm{Ha}$ Noi, http://vietnam.unfpa.org/
webdav/site/vietnam/shared/Disability_ENG.pdf (accessed on 25 May 2018).

[12] Tran Van Kham. (2014). Social construction of Disability and Its potential impacts on welfares Practice in Vietnamese contexts. SpringerPlus. 3: 325.

[13] Prime Minister. (2016). Decision No. 1100/QĐTTg Ratifying the plan for implementing the CRPD. Hanoi: Government of Vietnam.

[14] MOET. (2014). Vietnam National Education for All 2015 Review. Hanoi: Ministry of Education and Training.

[15] National Assembly. (2013). National Constitution of Socialist Republic of Vietnam (Amended). Hanoi: National Assembly.

[16] Ministry of Construction. (2014). National Technical Regulation on Construction for Disabled Access to Buildings and Facilities. Hanoi: Ministry of Construction.

[17] Prime Minister. (2012). National Action Plan to Support People with Disabilities for 2012-2020. Hanoi: Government of Vietnam.

[18] Rosenthal, E. (2009). The Rights of Children with Disabilities in Vietnam: Bringing Vietnam's Laws into compliance with the UN Convention on the Rights of Persons with Disabilities. Hanoi: UNICEF Vietnam

[19] MOET. (2018a). Circular No.03/2018/TT-BGDĐT on Inclusive Education for Persons with Disabilities. Hanoi: Ministry of Education and Training.

[20] Shirogane, K. (2016). The Socialization of Education Policy in Vietnam: Pursuing Quality Education for Children with Special Educational Needs. $18^{\text {th }}$ UNESOC UNESCO-APEID International Conference, October, Bangkok, Thailand.

http://www.unescobkk.org/fileadmin/user_upload/ apeid/Conference/18th_Conf2016/Papers/1.D.1Paper-KengoShirogane.pdf retrieved on September 3, 2018.

[21] MOET. (2018b). Education and Training Statistical Year Book Academic Year 2016-2017. Hanoi: Vietnam Education Publishing House.

[22] Dinh Thi Nga. (2017). Government investment on Education and Training: Current Status and Suggestions. Journal of Finance. http://tapchitaichinh.vn/nghien-cuu-trao-doi/dautu-cua-nha-nuoc-cho-giao-duc-dao-tao-thuc-trangva-mot-so-de-xuat-125673.html retrieved on September 3, 2018.

[23] MOET. (2017). Circular No. 05/2017/TTBGDĐT: Regulation on Full-time University Admission; Full-time College Admission in 
Teacher Training Fields. Hanoi: Ministry of Education and Training.

[24] MOET, MOLISA and MOF (2013). Joint circular No. 42/2013/TTLT-BGDĐT-BLĐTBXH-BTC: Regulation on education policy for people with disabilities. Hanoi: Ministry of Education and Training, Ministry of Finance, Ministry of Labour, Invalid and Society.

[25] Le Minh Hang. (2013). Opening the Gates for Children with Disabilities: An Introduction to
Inclusive Education in Vietnam. https://assets.aspeninstitute.org/content/uploads/fil es/content/docs/agent-orange/2013-10-

20_Le_Minh_HangInclusive_Education_for_CWD_in_VietnamEN.pdf retrieved on September $3^{\text {rd }}, 2018$.

[26] Nguyen, T.B. (2013). Barriers of Learning Quality of Disabled Children in Vietnam. Journal of Social Science, VNUH No. 2, pp. 64-71.

\title{
Môi trường học tập hoà nhập cho sinh viên khuyết tật trong giáo dục đại học ở Việt Nam - Một phân tích về các chính sách và khung khổ pháp luật
}

\author{
Nguyễn Thuỳ Anh \\ Truờng Đại học Kinh tế, ĐHQGHN, 144 Xuân Thủy, Cầu Giấy, Hà Nội, Việt Nam
}

Tóm tắt: Việt Nam là một trong các quốc gia có số lượng người khuyết tật lớn nhất trên thế giới. Theo cuộc Tổng Điều tra Dân số và Nhà ở năm 2009 có khoảng 6,1 triệu người khuyết tật, chiếm $7,8 \%$ dân số Việt Nam. Các nghiên cứu cho thấy số người khuyêt tật học đại học ở Việt Nam là rất thấp và chỉ có $0,1 \%$ người khuyết tật đã hoàn thành một chương trình đại học. Mục đích của bài viết là tổng quan tình hình người khuyết tật ở Việt Nam đồng thời phân tích khung khổ pháp luật và chính sách quốc gia liên quan đến người khuyết tật. Với mục đích này, bài viết trước hết trình bày các số liệu và thực trạng người khuyết tật ở Việt Nam. Tiếp đó bài viết khái quát các cam kết của Việt Nam đối với các chính sách và tiêu chuẩn quốc tế, cũng như khung khổ chính sách và pháp luật đối với người khuyết tật nói chung và sinh viên khuyết tật nói riêng. Cuối cùng bài viết chỉ ra một số vấn đề và thách thức đối với Việt Nam trong việc tạo dựng một môi trường học tập mang tính hoà nhập cho người khuyết tật và sinh viên khuyết trong giáo dục đại học.

Tù khoá: Người khuyết tật, Sinh viên khuyết tật, Giáo dục đại học ở Việt Nam, Môi trường học tập hoà nhập. 